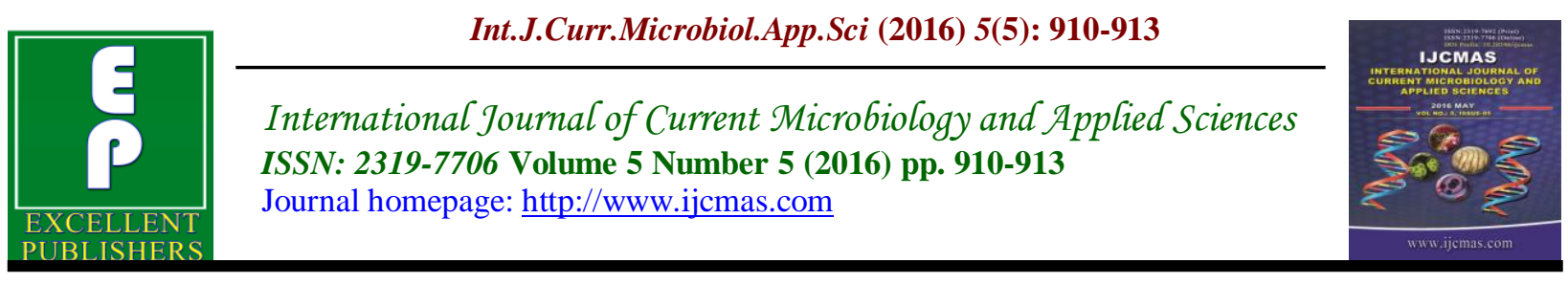

Original Research Article

http://dx.doi.org/10.20546/ijcmas.2016.505.094

\title{
Determination of LD50 Value of Zinc Chloride on Swiss Albino Mice
}

\author{
Satish Kumar Yadav and A.V. Trivedi* \\ Department of Chemistry, Carrier Point University, National Highway -12, Alaniya, \\ Kota 325003, Rajasthan, India \\ *Corresponding author
}

\begin{abstract}
A B S T R A C T
Keywords

Toxicity,

Swiss albino mice,

Standard error,

LD50 of zinc

chloride,

percentage

mortality.

Article Info

Accepted:

20 April 2016

Available Online:

10 May 2016

Toxicity of zinc chloride on Swiss albino mice of either sex was determined. Graphical method as described by Miller and Tainter was used for the determination of accurate value of LD50. Five groups of mice of either sex containing ten animals in each group were selected for the experiment. Five doses of zinc chloride which were near to the approximate LD50 viz., 1000, 1100, 1200, 1300 and $1400 \mathrm{mg} / \mathrm{kg} \mathrm{b}$. wt. were chosen and given orally. The animals were observed for 2 hour and then at 4, 6, 24, 72, and 96 hour for any toxic signs and symptoms. After 96 hour the number of deceased mice in each group was counted and \% mortality were calculated. LD50 of zinc chloride was found to be 1230 $\mathrm{mg} / \mathrm{kg}$ b.wt. The Standard error (SE) of the LD50 was calculated using the formula: Approx. SE of LD50 $=(\log \operatorname{LD} 84-\log \mathrm{LD} 16) / 2 \mathrm{~N}$, and found to be 129.69. Thus LD50 of zinc chloride $\left(\mathrm{ZnCl}_{2}\right)$ by oral route in Swiss albino mice was found to be $1230 \pm 129.69$ with $95 \%$ confidence level.
\end{abstract}

\section{Introduction}

Toxicity is a very - very important aspect of any biochemical or pharmacological experiment. Either we develop any metallo drug or a metal suppliment measurement of toxicity of that particular substance and parent substances is very important. The toxicity of a substance can be measured in many ways. Generally it is estimated on the test animal, viz. rats, mice, cat and other animal models. Acute toxicity of a substance can be measured by the calculation of LD50 i.e., the dose of a test substance that will kill $50 \%$ of the animals of a particular test species in a given period under controlled and standardised laboratory conditions.
LD50 is an initial screening step for the assesment of the toxic characteristic of a substance. An increasing dose is given to the test species and LD50 value is calculated based on the mortality of test species. In general, the smaller the LD50 value, the more toxic the test substance is and vice versa. Zinc is present in all body tissues and fluids. Now it is also considered as one of the important micro element in the biological system. Total body zinc content has been estimated to be approximately $2.0 \mathrm{~g}$ for an adult (Hambidge, 1987). Zinc is an essential component of a large number (>300) of enzymes participating in the synthesis and 
degradation of carbohydrates, lipids, proteins, and nucleic acids as well as in the metabolism of other micronutrients (Shankar \& Prasad, 1998; Zalewski, 1996). The immediate acute effects of overdose of this trace mineral are metallic taste in the mouth, headache, epigastric pain, lack of appetite, nausea, vomiting, abdominal pain, diarrhea and related gastrointestinal distress (Fosmire, 1990).Since it is a very important biometal thus determination of its toxicity in animal model is very-very important. Although median lethal dose of zinc is documented in rates (Domingo et al., 1988; Laura et al., 2010) but satisfactory data for LD50 of zinc in Swiss albino mice is not available. Therefore, an attempt was made to determine the acute oral LD50 of zinc chloride in Swiss albino mice using water as vehicle.

\section{Materials and Methods}

\section{Test Chemicals}

Reagent grade anhydrous zinc chloride $\left(\mathrm{ZnCl}_{2}\right)$ of $98 \%$ purity from Sigma Aldrich were used throughout the experiment.

\section{Animals and Experimental Design}

Male and female Swiss albino mice of 4 weaks older were used for this study. The mice were initially procured from the animal facilities, IVRI Izzatnagar, Bareilly (UP), India and a colony was established in the animal house facility. The mice were kept in polypropylene cages measuring $12 " \mathrm{x} 10^{\prime \prime} \mathrm{x}$ 8 " under standard laboratory conditions and $22 \pm 3^{\circ} \mathrm{C}$ temperature.

\section{Estimation of the Dose Range and Percentage Mortality}

An approximate LD50 was initially determined by pilot study the so called "up and down method" using two animals (Anwar, 1997; Randhawa, 2009) an incrasing dose of zinc chloride from 150 $\mathrm{mg} / \mathrm{kg}$ b.wt., $300 \mathrm{mg} / \mathrm{kg}$ b.wt., $600 \mathrm{mg} / \mathrm{kg}$ b.wt., $1200 \mathrm{mg} / \mathrm{kg}$ b.wt., and $2400 \mathrm{mg} / \mathrm{kg}$ b.wt. were given orally and an approximate LD50 $1200 \mathrm{mg} / \mathrm{kg}$ b.wt. were calculated. On the baises of the results of pilot study. i.e., approximate LD50 value we performed experiment for the determination of accurate value of LD50 using method of Miller and Tainter (Miller and Tainter, 1944). Five groups of mice of either sex containing ten animals in each group were selected for the experiment. Five doses of zinc chloride which were near to the approximate LD50 viz., 1000, 1100, 1200, 1300 and 1400 $\mathrm{mg} / \mathrm{kg} \mathrm{b}$. wt. were chosen and given orally and mortality were calculated. The animals were observed for 2 hour and then at 4, 6, 24, 72, and 96 hour for any toxic signs and symptoms. After 96 hour the number of deceased mice in each group was calculated. The percentage of mortality was calculated using the graphical method given by Miller and Tainer (Miller and Tainter, 1944)

\section{Results and Discussion}

\section{Observation for toxicity symptoms}

Initially, at lower dose of $150 \mathrm{mg} / \mathrm{kg} \mathrm{b}$. wt. did not produce any toxic effect. However, at higher doses, i.e. 1200 and $2400 \mathrm{mg} / \mathrm{kg}$ b.wt. animal showed common signs of toxicity. Symptoms of burying the heads in saw dust, abnormal gait, dullness, lethargy and hair shedding were exhibited by the treated animals.

Calculation of LD50 Value by the Conversion of Percentage Mortalities to Probit

The number of deceased mice was recorded for each dose level of zinc chloride which is shown in Table-1. The percentage mortality at each dose level were converted to probit using Finney's method (Table-2). 
A graph was than plotted between probit vs log dose and LD50 value of zinc chloride was determined by the graph which was the dose at probit 5.0 , i.e. $50 \%$ mortality. In the present case log dose at probit 5.0 was found to be 3.09 , i.e. $\log \operatorname{LD} 50=3.09$. Thus LD50 of zinc chloride was calculated by taking antilog of 3.09 and found to be 1230 $\mathrm{mg} / \mathrm{kg}$ b.wt.

Table.1 Effect of Lethal Dose of $\mathrm{ZnCl}_{2}$ After Oral Adminstration to Swiss Albino Mice $(n=10)$

\begin{tabular}{|c|c|c|c|c|}
\hline Group & $\begin{array}{c}\text { Dose } \\
(\mathbf{m g} / \mathbf{k g})\end{array}$ & Log Dose & \% Dead & Probits \\
\hline $\mathbf{1}$ & 1000 & 3.00 & 20 & 4.16 \\
\hline $\mathbf{2}$ & 1100 & 3.04 & 30 & 4.48 \\
\hline $\mathbf{3}$ & 1200 & 3.08 & 40 & 4.75 \\
\hline $\mathbf{4}$ & 1300 & 3.11 & 60 & 5.25 \\
\hline $\mathbf{5}$ & 1400 & 3.15 & 80 & 5.84 \\
\hline
\end{tabular}

Table.2 Transformation of Percentage Mortalities to Probit

\begin{tabular}{|c|c|c|c|c|c|c|c|c|c|c|}
\hline $\boldsymbol{\%}$ & $\mathbf{0}$ & $\mathbf{1}$ & $\mathbf{2}$ & $\mathbf{3}$ & $\mathbf{4}$ & $\mathbf{5}$ & $\mathbf{6}$ & $\mathbf{7}$ & $\mathbf{8}$ & $\mathbf{9}$ \\
\hline $\mathbf{0}$ & - & 2.67 & 2.95 & 3.12 & 3.25 & 3.36 & 3.45 & 3.52 & 3.59 & 3.66 \\
\hline $\mathbf{1 0}$ & 3.72 & 3.77 & 3.82 & 3.87 & 3.92 & 3.96 & 4.01 & 4.05 & 4.08 & 4.12 \\
\hline $\mathbf{2 0}$ & 4.16 & 4.19 & 4.23 & 4.26 & 4.29 & 4.33 & 4.36 & 4.39 & 442 & 4.45 \\
\hline $\mathbf{3 0}$ & 4.48 & 4.50 & 4.53 & 4.56 & 4.59 & 4.61 & 4.64 & 4.67 & 4.69 & 4.72 \\
\hline $\mathbf{4 0}$ & 4.75 & 4.77 & 4.80 & 4.82 & 4.85 & 4.87 & 4.90 & 4.92 & 4.95 & 4.97 \\
\hline $\mathbf{5 0}$ & 5.00 & 5.03 & 5.05 & 5.08 & 5.10 & 5.13 & 5.15 & 5.18 & 5.20 & 5.23 \\
\hline $\mathbf{6 0}$ & 5.25 & 5.28 & 5.31 & 5.33 & 5.36 & 5.39 & 5.41 & 5.44 & 5.47 & 5.50 \\
\hline $\mathbf{7 0}$ & 5.52 & 5.55 & 5.58 & 5.61 & 5.64 & 5.67 & 5.71 & 5.74 & 5.77 & 5.81 \\
\hline $\mathbf{8 0}$ & 5.84 & 5.88 & 5.92 & 5.95 & 5.99 & 6.04 & 6.08 & 6.13 & 6.18 & 6.23 \\
\hline $\mathbf{9 0}$ & 6.28 & 6.34 & 6.41 & 6.48 & 6.55 & 6.64 & 6.75 & 6.88 & 7.05 & 7.33 \\
\hline
\end{tabular}

\section{Calculation of Standard Error (SE) of LD50}

The SE of the LD50 was calculated using the following formula (Ghosh, 1984)

Approx. SE of LD50 $=(\log$ LD84 $-\log$ LD16) / 2N.

where $\mathrm{N}$ is number of animals in each group.

The probits of 84 and 16 from Table - 2 were seen to be 5.99 and 4.01 (approximately 6 and 4) respectively. The Log LD values corresponding to probits 6 and 4 were obtained from the line of the graph of probit vs Log dose. In the present case these values were found to be 3.194 and 2.984 respectively and antilog of these values were 1564 and 964 respectively. Puttig these values to equation SE were calculated to be 129.69 . Thus LD50 of zinc chloride $\left(\mathrm{ZnCl}_{2}\right)$ by oral rout is $1230 \pm 129.69$ with $95 \%$ confidence level.

Toxicological examination of a substance is very-very important. This can be useful to 
measure the acute toxicity of a substance, food poisoning and accidental domestic poisoning. The information gained from dose response studies in animals used to set standards for human exposure. In the present case LD50 of zinc chloride was determined and found to be $1230 \pm 129.69$ with $95 \%$ confidence level in Swiss albino mice. Zinc is present in all body tissues and fluids. Now it is also considered as one of the important micro element in the biological system. Since it is a very important biometal thus determination of its toxicity in animal model is very-very important for development of a new metallo drug or a metal suppliment. Although median lethal dose of zinc is documented in rates (Domingo et al., 1988; Laura et al., 2010) but satisfactory data for LD50 of zinc in Swiss albino mice is not available. Therefore, this study were carried out and LD50 of zinc chloride was determined.

\section{Acknowledgement}

Authors thanks Carrier Point University Kota (Rajasthan) and Dr. Gurudatt Kakkar for their needful help.

\section{References}

Anwar, W.A. 1997. Biomakers of human exposure to pesticides. Environ Health Perspect, 105, Suppl 4, 801806.

Domingo, J.L., Llobet, J.M., Corbella, J.
1988. Acute zinc intoxication: comparison of the antidotal efficacy of several chelating agents. Vet. Hum. Toxicol., 30: 224 - 228.

Fosmire, G.J. 1990. Zinc toxicity. Am. J. Clin. Nutr., 51(2): 225.

Ghosh, M.N. 1984. Fundamental of Experimental Pharmacology. Scientific Book Agency Calcutta, Pp 187-189.

Hambidge, K.M. 1987. Zinc. In: Trace elements in human and animal nutrition. (Eds) Mertz, W., Orlando, Florida, Academic Press, Inc.Vol. 1 Pp 1-37

Laura, M. Plum, Lother, R., Hajo Haase. 2010. The essential toxin : impect of zinc on human health. J. Environ. Res. Public Health, 7: 1342 - 1365.

Miller, L.C., Tainter, M.I. 1944. Estimation of LD50 and its error by means of log - probit graph paper. Proc. Soc. Exp. Bio. Med., 57: 261.

Randhawa, M.A. 2009. Calculation of LD50 values from the method of Miller and Tainter, 1944. J. Ayub. Med. Coll. 3: 21.

Shankar, A.H., Prasad, A.S. 1998. Zinc and immune function: the biological basis of altered resistance to infection. Am. J. Clin. Nutr., 68.

Zalewski, P.D. 1996. Zinc and immunity: implications for growth, survival and function of lymphoid cells. J. Nutr. Immunol., 4: 39-80.

\section{How to cite this article:}

Satish Kumar Yadav and A.V. Trivedi. 2016. Determination of LD50 Value of Zinc Chloride on Swiss Albino Mice. Int.J.Curr.Microbiol.App.Sci. 5(5): 910-913.

doi: http://dx.doi.org/10.20546/ijcmas.2016.505.094 